\title{
PRODUKSI TANAMAN TOMAT (Solanum lycopersicum L.) \\ DENGAN PEMBERIAN SP-36 DAN DOLOMIT DI TANAH GAMBUT
}

\author{
Mardaus ${ }^{1}$, , Intan Sari, SP.MP ${ }^{2}$, Elfi Yenny Yusuf, SP. MSi ${ }^{2}$ \\ Agroteknologi Fakultas Pertanian UNISI \\ Email:
}

\begin{abstract}
Reseach the ifluece ofthe produktion of a crop tomatos. By the SP-36 and dolomite in peat soil hasee implementd in the garden experiment the fakulty of agrikultureUNISI Riau provice.During 4 month from may to the augustus. reseach purpose the provision of avariety ofdoses to SP-36 and dolomite crop of tomato plants in the lads of peat. $\quad$ Mediumused to a SP-36 and dolomite, 200kg SP-36/Ha+2Ton, 200kg SP-36/Ha+3Ton, 200kg SP-36/Ha+4Ton, 250kg SP-

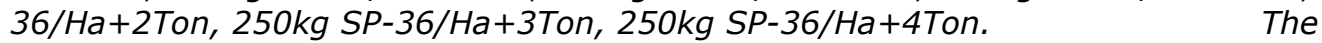
experimetwork on this useful the parameter observation the ground, $\mathrm{pH}$ tall pland, the age of flower theage ofthe frist fruit, heavy brangkas dry. Data analyzedy by obervation ingerprint variety of(ANOVA) and continiued by test further HSD 5\% perpecent during the preparattory pheseof turkey the of various doses of combinasi already afford uprade production crop tomato whit the highest on the in creased production of treatment $250 \mathrm{~kg} \mathrm{SP}-36 / \mathrm{Ha}+4$ Tons dolomite/Ha, against the age of flowering recorder on treatment $200 \mathrm{~kg} \mathrm{SP-36/ha+4} \mathrm{Tons} \mathrm{dolomite/Ha,} \mathrm{the} \mathrm{frist} \mathrm{crop} \mathrm{to} \mathrm{the} \mathrm{age} \mathrm{of} \mathrm{the} \mathrm{fas} \mathrm{test}$

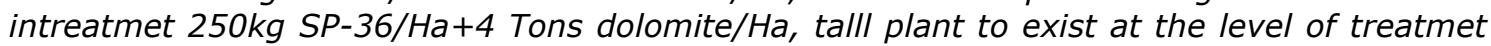
$250 \mathrm{~kg} \mathrm{SP}-36 / \mathrm{Ha}+4$ Tons dolomite/Ha, on the increase intreatment exsist at the level of $\mathrm{pH} 4$ Ton dolomite/Ha againt brangkasan dry planet on the highest treatment $250 \mathrm{~kg}$ SP-36/Ha+4 Ton dolomite/Ha.
\end{abstract}

\begin{abstract}
Abstrak
Penelitian pengaruh produksi tanaman tomat (Solanum lycopersicum L.) dengan pemberian SP-36 dan dolomit di tanah gambut telah dilaksanakan di Kebun Percobaan Fakultas Pertanian UNISI Kabupaten Indragiri Hilir Propinsi Riau selama 4 bulan dari bulan Mei sampai dengan Agustus 2016. Tujuan dari penelitian ini adalah untuk mengetahui pengaruh pemberian berbagai dosis SP-36 dan Dolomit terhadap produksi tanaman tomat di tanah gambut.

Media yang digunakan adalah tanah gambut dengan perlakuan dosis SP-36 dan dolomit, $200 \mathrm{~kg} \mathrm{SP}-36 / \mathrm{Ha}+2 \mathrm{Ton} / \mathrm{Ha}, 200 \mathrm{~kg} \mathrm{SP}-36 / \mathrm{Ha}+3 \mathrm{Ton} / \mathrm{Ha}, 200 \mathrm{~kg} \mathrm{SP}-36 / \mathrm{Ha}$

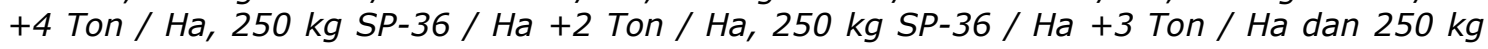
SP-36/ Ha +4 Ton / Ha.

Parameter pengamatan pada penelitian ini yaitu, pH tanah, tinggi tanaman, umur berbunga, umur panen pertama, berat buah pertanaman dan berat brangkasan kering. Data pengamatan dianalisis dengan sidik ragam (ANOVA) dan dilanjutkan dengan uji lanjut Turkey HSD pada tahaf $5 \%$. Pemberian berbagai dosis kombinasi SP-36 dan dolomit yang telah dicoba mampu meningkatkan produksi tanaman tomat di tanah gambut. Peningkatan produksi yang tertinggi terdapat pada perlakuan $250 \mathrm{~kg} \mathrm{SP}-36 / \mathrm{Ha}+4$ ton dolomit / $\mathrm{Ha}$, terhadap umur berbunga tercepat pada perlakuan $200 \mathrm{~kg} \mathrm{SP}-36 / \mathrm{Ha}+4$ ton dolomit / $\mathrm{Ha}$, terhadap umur panen pertama tercepat pada perlakuan $250 \mathrm{~kg} \mathrm{SP}-36 / \mathrm{Ha}+4$ ton dolomit /

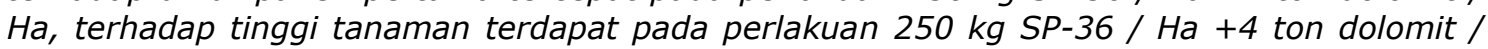
$\mathrm{Ha}$, terhadap peningkatan $\mathrm{pH}$ terdapat pada perlakuan 4 ton dolomit/Ha dan terhadap
\end{abstract}


berangkasan kering tanaman yang tertinggi pada perlakuan $250 \mathrm{~kg}$ SP-36 / Ha +4 Ton dolomit / Ha.

Kata kunci: Tomat Tymoti, SP-36, Dolomit, Tanah Gam

\section{PENDAhUlUAN}

\subsection{Latar Belakang}

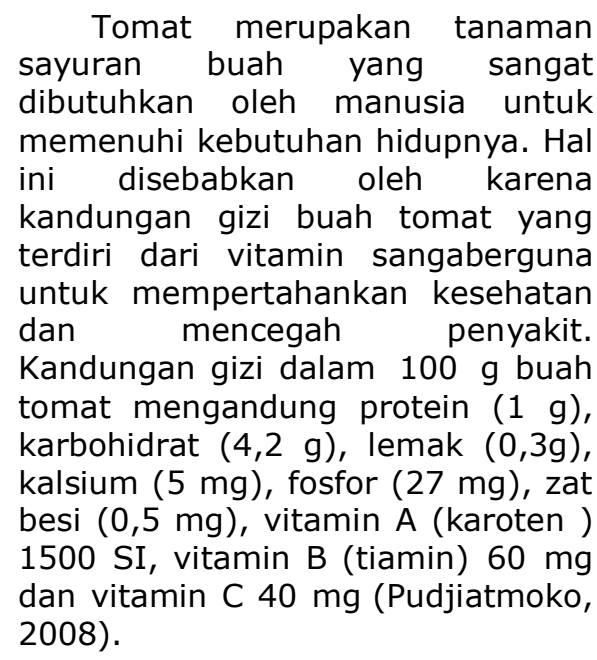

Kebutuhan tomat untuk konsumsi setiap tahun meningkat, akan tetapi untuk produksi tanaman tomat tidak seterusnya mengalami peningkatan. Menurut Badan Pusat Statistik (2014), produksi tomat di Indonesia pada 3 tahun terakhir, dimulai dari tahun 2011 mengalami penurunan produksi mencapai 847.160 ton dari luas panen 56,724 ha sehingga produktivitas sebesar 15,75 ton/ha, tahun 2012 mengalami peningkatan produksi mencapai 994,780 ton dengan luas panen 57,758 ha sehingga produktivitas mencapai 16,65 ton/ha dan pada tahun 2013 mengalami penurunan produksi mencapai 893,504 ton dari luas panen 56,724 ha sehingga produktivitas 15,75 ton/ha. Produksi tomat Riau tahun 2011 di tanah gambut adalah 146 ton dengan produktifitasnya hanya 2.52 ton/ha sedangkan produktifitas Nasional mencapai ).16.65 ton/ha (Badan Pusat Stastistik dan Direktorat Jendral Hortikultura, 2012.

$$
\text { Tanah gambut }
$$

mempunyai masalah kekurangan unsur hara dan $\mathrm{pH}$ rendah sehingga menjadi kendala dalam budidaya di tanah gambut. Menurut Lingga dan Marsono (2007) mengatakan bahwa, salah satu usaha agar tanaman dapat tumbuh baik pada tanah gambut yang memiliki tingkat keasaman yang tinggi dapat

dilakukan dengan menambahkan
dolomit.

Menurut Widodo (2000), penambahan dolomit 2-4 ton/ha dapat menaikan $\mathrm{pH}$ tanah antara $1-2$ satuan, sehingga tanah dapat mencapai $\mathrm{pH}$ 5,29-6,29 dan ini akan ideal untuk perkembangan tanaman tomat. Sedangkan menurut Subagyo (2000) kesuburan gambut yang rendah karena kandungan hara yang rendah dan reaksi tanah yang masam, secara tidak langsung menyebabkan pertumbuhan menjadi lambat.

\section{Melambatnya}

pertumbuhan tanaman dikarenakan kekurangan unsur hara $P$, karena $P$ berperan dalam proses fotosintesis, penggunaan gula dan pati, serta transfer energi. Pemberian pupuk SP36 ke tanah dapat meningkatkan pertumbuhan dan hasil tanaman (Novizan, 2007). Pupuk SP 36 mengandung 36\% fosfor dalam bentuk $\mathrm{P}_{2} \mathrm{O}_{5}$. Pupuk ini terbuat dari fosfat alam dan sulfat, berbentuk butiran dan bewarna abu-abu. Sifatnya agak sulit larut di dalam air dan bereaksi lambat sehingga selalu digunakan sebagai pupuk dasar. Reaksi kimianya tergolong netral, tidak higroskopis dan tidak bersifat membakar (Novizan, 2007). Menurut Purwono dan Purnamawati (2009), dosis anjuran rata-rata pupuk SP-36 200 kg/ha untuk tanaman tomat di lahan gambut.

1.2 Berdasarkan dari uraian diatas maka perlu adanya penelitian mengenai produksi tanaman tomat (Solanum lycopersicum L.) dengan pemberian SP-36 dan dolomit di tanah gambut.

\subsection{Rumusan Masalah}

Berkaitan dengan masalah yang diatasi maka dapat dirumuskan sebagai berikut :

1. Bagaimana produksi tanaman tomat (Solanum lycopersicum L.) di tanah gambut dengan pemberian SP-36 dan dolomit.

2. Berapakah dosis yang optimal untuk produksi tanaman tomat (Solanum lycopersicum L.) di tanah gambut dengan pemberian SP-36 dan dolomit.

\subsection{Tujuan Penelitian}


1. Untuk mengetahui produksi tanaman tomat (Solanum lycopersicum L.) di tanah gambut dengan pemberian SP-36 dan dolomit.

2. Mengetahui dosis SP-36 dan dolomit yang optimal untuk meningkatkan produksi tomat (Solanum lycopersicum L.) di tanah gambut.

1.4 Manfaat Penelitian

1. Dapat dijadikan sebagai acuan petani untuk meningkatkan produksi tanaman tomat (Solanum lycopersicum L.) di tanah gambut dengan pemberian SP-36 dan dolomit.

2. Menjadi referensi tambahan bagi mahasiswa, khususnya mahasiswa Fakultas Pertanian Program Studi Agroteknologi.

\section{TINJAUAN PUSTAKA}

\subsection{Botani Tanaman Tomat ( Solanum Iycopersicum L.)}

Bentuk botani tanaman dalam sistematika (taksonomi) tumbuhan, kedudukan tanaman tomat diklasifikasikan sebagai berikut :

$\begin{array}{ll}\text { Kingdom } & : \text { Plantae } \\ \text { Divisio } & : \text { Spermatophyta } \\ \text { Subdivisio } & : \text { Angiospermae } \\ \text { Kelas } & : \text { Dicotyledonae } \\ \text { Ordo } & : \text { Solanales } \\ \text { Family } & : \text { Solanaceae } \\ \text { Genus } & : \text { Solanum } \\ \text { Spesies } & : \text { Solanum }\end{array}$

lycopersicum L.

Tanaman tomat merupakan tanaman dari Solanaceae, berasal dari daerah Amerika Tengah dan Selatan, dari Meksiko sampai Peru. Tomat merupakan tanaman semusim (berumur pendek) yang artinya tanaman tomat hanya mampu satu kali berproduksi dan kemudian mati. Tanaman tomat berbentuk perdu yang panjangnya dapat mencapai 3 meter (Cahyono, 2008). Tanaman tomat dapat tumbuh diberbagai ketinggian tempat, baik dataran rendah maupun dataran tinggi (Adiyoga $d k k, 2004$ ). $\mathrm{Biji}$ tomat berbentuk pipih, berbulu dan diselimuti daging buah. Warna biji ada yang putih, putih kekuningan dan ada juga kecoklatan. Biji inilah yang umumnya dipergunakan untuk perbanyakan tanaman (Wiryanta, 2002).

\subsection{Syarat Tumbuh Tanaman Tomat}

Tanaman tomat memiliki beberapa persyaratan untuk tumbuh diantaranya :

a) Iklim
Curah hujan yang sesuai untuk pertumbuhan tanaman tomat adalah 750 $\mathrm{mm}-1.250 \mathrm{~mm} /$ tahun. Keadaan ini berhubungan erat dengan ketersediaan air tanah bagi tanaman, terutama di daerah yang tidak terdapat irigasi teknis. Curah hujan yang tinggi (banyak hujan) juga dapat menghambat persarian (Pudjiatmoko, 2008).

Kekurangan sinar matahari menyebabkan tanaman tomat mudah terserang penyakit, baik parasit maupun non parasit. Sinar matahari berintensitas tinggi akan menghasilkan vitamin $\mathrm{C}$ dan karoten (provitamin A) yang lebih tinggi. Penyerapan unsur hara yang maksimal oleh tanaman tomat akan dicapai apabila pencahayaan selama 12-14 jam/hari, sedangkan intensitas cahaya yang dikehendaki adalah $0,25 \mathrm{mj} / \mathrm{m} 2$ per jam (Pudjiatmoko, 2008).

Suhu udara rata-rata harian yang optimal untuk pertumbuhan tanaman tomat adalah suhu siang hari 18-29 derajat $\mathrm{C}$ dan pada malam hari 10-20 derajat $C$ (Pudjiatmoko, 2008).

Kelembaban relatif yang tinggi sekitar $25 \%$ akan merangsang pertumbuhan untuk tanaman tomat yang masih muda karena asimilasi $\mathrm{CO} 2$ menjadi lebih baik melalui stomata yang membuka lebih banyak. Tetapi, kelembaban relatif yang tinggi juga merangsang mikro organisme pengganggu tanaman (Pudjiatmoko, 2008).

\section{b) Media Tanam}

Tanaman tomat dapat ditanam di segala jenis tanah, mulai tanah pasir sampai tanah lempung berpasir yang subur, gembur, banyak mengandung bahan organik serta unsur hara dan mudah merembeskan air. Selain itu akar tanaman tomat rentan terhadap kekurangan oksigen, oleh karena itu air tidak boleh tergenang (Pudjiatmoko, 2008).

Tanah dengan derajat keasaman $(\mathrm{pH})$ berkisar 5,5-7,0 sangat cocok untuk budidaya tomat (Pudjiatmoko, 2008).

Dalam pembudidayaan tanaman tomat, sebaiknya dipilih lokasi yang topografi tanahnya datar, sehingga tidak perlu dibuat teras-teras dan tanggul (Pudjiatmoko, 2008).

\section{C) Ketinggian Tempat}

Tanaman tomat dapat tumbuh di berbagai ketinggian tempat, baik di dataran tinggi maupun di dataran rendah, tergantung varietasnya. Tanaman tomat yang sesuai untuk ditanam di dataran tinggi misalnya varietas berlian, varietas mutiara, varietas kada. Sedangkan varietas yang sesuai ditanam di dataran rendah misalnya varietas Intan, varietas Ratna, varietas 
Berlian, varietas LV, varietas CLN. Selain itu, ada varietas tanaman tomat yang cocok ditanam di dataran rendah maupun di dataran tinggi antara lain varietas tomat $\mathrm{GH}$ 2, varietas tomat $\mathrm{GH}$ 4, varietas erlian, varietas Butiara (Pudjiatmoko, 2008).

\subsection{Tanah Gambut}

Menurut Darmawi (1999) dalam Fauzi, (2010) menjelaskan tanah gambut merupakan akumulasi sisa-sisa tanaman yang mengalami humifikasi lebih besar dari mineralisasi pada kadar air yang berlebihan dan membentuk endapan-endapan yang mengandung bahan organik dalam persentase yang sangat tinggi. Lahan gambut mempunyai kandungan bahan organik lebih besar dari $20 \%$ atau mempunyai ketebalan bahan organik lebih besar dari 50 $\mathrm{cm}$.

Menurut Agus dan Subiksa (2008), bahan organik penyusun tanah gambut terbentuk dari sisa-sisa tanaman yang belum melapuk sempurna karena kondisi lingkungan jenuh air dan miskin hara. Oleh karenanya lahan gambut banyak dijumpai di daerah rawa atau daerah cekungan yang drainasenya buruk. Kemasaman tanah ditentukan oleh kadar atau kepekaan ion hidrogen yang beredar di dalam tanah tersebut. Bila kepekatan ion hidrogen $\left(\mathrm{H}^{+}\right)$ itu dalam tanah terlalu tinggi maka tanah tersebut asam.Sebaliknya, bila kepekatan ion terlalu rendah maka tanah tersebut basa (Lingga dan Marsono, 2007).

Lahan gambut yang dapat dimanfaatkan untuk tanaman pangan disarankan pada gambut dangkal (< 100 $\mathrm{cm}$ ). Dasar pertimbangannya adalah gambut dangkal memiliki tingkat kesuburan relatif lebih tinggi dan memiliki resiko lingkungan lebih rendah dibandingkan gambut dalam. Pengembangan pertanian pada lahan gambut menghadapi banyak kendala yang berkaitan sifat tanah gambut. Secara umum sifat kimia tanah gambut didominasi oleh asam-asam organik yang merupakan suatu hasil akumulasi sisa-sisa tanaman. Asam organik yang dihasilkan tersebut merupakan bahan yang bersifat racun bagi tanaman, sehingga mengganggu proses metabolisme tanaman yang akan berakibat langsung terhadap produktivitasnya. Sementara itu, secara fisik tanah gambut bersifat lebih berpori dibandingkan tanah mineral. Hal ini akan mengakibatkan cepatnya pergerakan air pada gambut yang belum terdekomposisi dengan sempurna, sehingga jumlah air bagi tanaman sangat terbatas (Agus dan Subiksa, 2008).
Tanah gambut sebagai media tumbuh tanaman memerlukan berbagai input untuk menciptakan kondisi optimal bagi tumbuhan dan perkembangan tanaman yang dibudidayakan. Variasi input yang pernah dilakukan adalah pemberian pupuk $\mathrm{P}, \mathrm{Cu}$, pengapuran, pemberian abu, pupuk kandang ayam, pemberian tanah mineral, pengolahan tanah serta melakukan seleksi pada tanaman budidaya yang mampu beradaptasi pada lingkungan tanah gambut (Handayani, 2004).

\subsection{Fospat}

Fosfor (P) termasuk unsur hara makro yang sangat penting untuk pertumbuhan tanaman, namun kandungan didalam tanaman lebih rendah dibandingkan nitrogen (N), kalium (K) dan kalsium (Ca). tanaman menyerap $\mathrm{P}$ dari tanah dalam bentuk ion fosfat, terutama $\mathrm{H}_{2} \mathrm{PO}_{4}{ }^{-}$dan $\mathrm{HPO}_{4}{ }^{2-}$ yang terdapat dalam larutan tanah. Ion $\mathrm{H}_{2} \mathrm{PO}_{4}{ }^{-}$lebih banyak dijumpai pada tanah yang lebih masam, sedangkan pada $\mathrm{pH}$ yang lebih tinggi $(<7)$ bentuk $\mathrm{HPO}_{4}{ }^{2-}$ lebih dominan. Disamping ion-ion tersebut, tanaman dapat menyerap $P$ dalam bentuk asam nukleat, fitin dan fosfohumat (Nurita dan Anwar, 2007).

Fosfat merupakan kunci kehidupan karena hampir terlibat pada semua proses metabolisme dan merupakan sumber ATP. Peluang hilangnya fosfat dari tanah dapat diketahui sangat kecil dan hilangnya fosfat bersama panen relatif juga kecil karena fosfat yang diserap tanaman hanya berkisar $10 \%$ dari takaran pupuk yang diberikan, sehingga terjadi penumpukan fosfat yang diberikan pemupukan fosfat yang sangat berat (Taher, 2007).

Pergerakan fosfat pada umumnya disebabkan proses difusi, tetapi jika kandungan $\mathrm{P}$ larutan tanah cukup tinggi, maka proses aliran massa dapat berperan dalam tranfortasi tersebut. Ion yang berada dipermukaan akar akan menuju rongga luar akar melalui proses difusi sederhana. Selanjutnya ion memasuki rongga akar dengan melibatkan energi metabolisme, yang dikenal sebagai serapan aktif (Yakpa $d k k, 1988)$.

Pada tanah masam, $\mathrm{P}$ bersenyawa dalam bentuk Al-P, Fe-P dan Occluded-P, sedangkan pada tanah bereaksi basa pada umumnya $P$ bersenyawa sebagai Ca- $P$, adanya pengikatan-pengikatan $\mathrm{P}$ tersebut menyebabkan pupuk $P$ yang diberikan menjadi tidak efesien sehingga perlu diberikan dalam takaran yang tinggi. Menurut Jones (1979), tanaman memanfaatkan P Hanya $10-30 \%$ dari pupuk 
$P$ yang diberikan, berarti pupuk $P$ tetap berada didalam tanah.

Unsur fosfat sangat penting oleh tanaman pada saat pembentukan biji sehingga menjadi bentuk sempurna, para ahli mengemukakan bahwa fosfor juga berguna untuk mempercepat pemasakan buah dan menstimulir pembentukan akar pada awal pertumbuhan, bentuk pupuk yang mengandung $\mathrm{P}$ diantaranya adalah super posfat, TSP, SP-36 dan asam pospat (Sugito, 2002).

Pemupukan $\mathrm{P}$ pada lahan sulfat masam sangat penting. Beberapa peneliti menganjurkan penggunaan pupuk konvensional seperti pupuk SP-36 karena saat ini paling umum dipakai sebagai sumber $\mathrm{P}$ karena pupuk ini tersedia di pasar (Parinduri, 2011).

\subsection{Dolomit}

Dolomit adalah mineral yang berasal dari alam yang mengandung unsur hara magnesium dan kalsium dengan kandungan kimia $\mathrm{CaMg}(\mathrm{CO} 3)_{2}$. Jika ukuran $\mathrm{pH}$ tanah terlalu asam, untuk mengatasi bisa dilakukan pemberian dolomit. Selain berguna untuk menaikan $\mathrm{pH}$, senyawa $\mathrm{Ca}$ dan $\mathrm{Mg}$ pada dolomit juga mampu menekan dan menetralkan sifat buruk yang unsurunsur yang berpotensi meracuni tanaman. Pemberian dolomit juga menciptakan sruktur tanah menjadi lebih baik, sehingga microorganisme dapat hidup dan berkembang dengan baik (Hakim dkk 1986).

Kalsium dapat diserap dalam bentuk $\mathrm{Ca} 2^{+}$, sebagian besar terdapat dalam daun dalam bentuk kalsium peklay yaitu dalam lamella pada dinding sel, terdapat juga pada batang, berpengaruh baik pada pertumbuhan ujung dan pembulu akar (Noor, 2001). Peranan Ca adalah pembentuk protein, mengatur struktur membran dan aktifasi terutama pada aliran ion di akar, proses pembentukan membran, Menetralkan asam Organik dari hasil metabolisme. Sumber Ca terutama batu-batuan kapur dan sisa-sisa tanaman. Defisiensi Ca menyebabkan terhambatnya sistem perakaran dan fungsi akar. Gejala yang diperlihatkan bila tanaman kekurangan Ca adalah daun yang berubah warna dan berkerut dan kuncup daun yang telah tumbuh pun mati.

Magnesium diserap dalam $\mathrm{Mg}^{2+}$ merupakan bagian dari krolofil. Kadar Mg dibagian-bagian vegetatif dapat dinyatakan rendah dari pada $\mathrm{Ca}$, akan tetapi didalam bagian-bagian generatif malah sebaliknya. Mg banyak terdapat dalam buah dan juga didalam tanah (Noor, 2001).
Rendahnya produksi tomat, dapat dikarenakan luas lahan budidaya tomat masih tergolong rendah dan lahan yang digunakan mempunyai tingkat kesuburan yang rendah salah satunya berupa tanah gambut. Upaya untuk memperbaiki keadaan tanah gambut tersebut dapat dilakukan salah satunya dengan pemberian kapur dolomit dalam jumlah yang cukup (Yanti, 2015).

\section{METODOLOGI PENELITIAN}

\subsection{Waktu Dan Tempat}

Penelitian ini telah dilaksanakan selama 4 bulan dimulai dari bulan Mei sampai Agustus 2016. Dilaksanakan di kebun Percobaan di Fakultas Pertanian Jl. Lintas Propinsi Parit 01, Desa Pulau Palas, Kecamatan Tembilahan Hulu, Kabupaten Indragiri Hilir (Lampiran 1).

\subsection{Bahan dan Alat}

Bahan benih tomat hibrida Tymoti dibeli dari Surabaya, polibag, Dolomit, pupuk SP-36, Fungisida Dithane M-45, Insektisida Sevin 85 SP, air. Alat yang digunakan dalam penelitian ini adalah, cangkul, parang, gembor, tali rafia, hand sprayer, gelas aqua mineral, bambu, meteran, pisau, gunting, papan sampel, kamera, timbangan, kalkulator dan alat tulis.

\subsection{Metode Penelitian}

Penelitian ini dilakukan dengan menggunakan Rancangan Acak Lengkap (RAL) non faktorial. Penelitian ini terdiri dari 7 perlakuan dan 3 ulangan, setiap perlakuan terdiri dari 3 tanaman, yaitu :

$\mathrm{HO}=$ Tanah Gambut

$\mathrm{H} 1$ = Tanah Gambut +200 kg SP-36/Ha + 2 ton dolomit/ $\mathrm{Ha}$

$\mathrm{H} 2$ = Tanah Gambut +200 kg SP-36/Ha + 3 ton dolomit/ $\mathrm{Ha}$

H 3 = Tanah Gambut + 200 kg SP-36/Ha + 4 ton dolomit/ $\mathrm{Ha}$

$\mathrm{H} 4$ = Tanah Gambut +250 kg SP-36/Ha + 2 ton dolomit/ $\mathrm{Ha}$

$\mathrm{H} 5=$ Tanah Gambut + 250 kg SP-36/Ha + 3 ton dolomit/ $\mathrm{Ha}$

H 6 = Tanah Gambut + 250 kg SP-36/Ha + 4 ton dolomit/ $\mathrm{Ha}$

Hasil penelitian dianalisis dengan

menggunakan sidik ragam Turkey HSD taraf $5 \%$ berdasarkan model linier sebagai berikut $Y i j=\mu+T i+\varepsilon i j$

Yij = Hasil pengamatan pada perlakuan ke-i

dan ulangan ke-j

$\mu \quad=$ rataan umum

$\mathrm{Ti}=$ pengaruh perlakuan ke-i 
$\varepsilon \mathrm{ij}=$ pengaruh acak pada perlakuan ke-I ulangan ke-j

\subsection{Pelaksanaan Penelitian 2.4.1 Persiapan Media}

Tanah yang digunakan terlebih dahulu dibersihkan dari sisa tanaman dan gulma. Setelah bersih tanah dikering angin yang dicirikan air tidak menetes jika tanah diangkat. Bongkahan dihancurkan sehingga tanah hingga gembur.

\subsubsection{Penyemaian Benih}

Sebelum melakukan penyemaian benih maka dilakukan perendaman benih selama 15 menit kedalam air hangat-hangat kuku. Setelah perendaman biji dimasukan kedalam gelas air mineral $220 \mathrm{ml}$ yang telah diisi media dari tanah gambut dan pupuk kandang digunakan dengan perbandingan $2: 1$. Setelah dilakukan penyemaian benih gelas mineral tersebut disusun dengan rapi dan diberi naungan agar terjaga kelembaban dan tidak terkena cahaya matahari secara langsung sehingga benih dapat tumbuh dengan baik.

\subsubsection{Persiapan Media Tanam}

Media yang terdiri dari tanah gambut yang telah dikering anginkan. Media dipisahkan dari gulma dan pecahkan dari bongkahan hingga gembur. Kemudian media dimasukan kedalam polibag berukuran $20 x$ $50 \mathrm{~cm}$.

\subsubsection{Pengapuran}

Pengapuran diberikan saat media dilapangan sebelum dimasukkan ke dalam polibag. Cara pemberiannya dengan mengaduk kapur dengan media sehingga tercampur dengan merata sesuai masingmasing perlakuan. Setelah pengapuran tanah diinkubasi selama satu minggu. Pengapuran diberikan sesuai perlakuan (Lampiran 5).

\subsubsection{Pemupukkan}

Pemupukkan SP-36 dilakukan untuk menambah unsur hara yang dibutuhkan tanaman. Pemberian pupuk dilakukan dengan menabur disekitar pangkal tanaman dengan jarak $10 \mathrm{~cm}$. Pemberian pupuk dilakukan saat penanaman sesuai perlakuan (Lampiran 5).

\subsubsection{Pemasangan Label}

Label yang sudah disiapkan dipasang sesuai lay out penelitian dengan perlakuan masing-masing sebagaimana terlampir pada lay out penelitian. Label dipasang pada sampel penelitian (Lampiran 2).

\subsubsection{Penanaman}

Setelah bibit berumur 4 minggu dilakukan seleksi bibit dengan kriteria bibit sehat, batang kokoh, tidak cacat, dan tidak terserang hama penyakit serta mempunyai daun 4-5 helai daun. Bibit hasil seleksi ditanam dalam polibag yang berukuran $20 \times 50 \mathrm{~cm}$ dengan kedalaman $10 \mathrm{~cm}$. I

\subsubsection{Pemasangan Ajr}

Setelah penanaman setiap batang tomat diberikan ajir supaya tanaman tidak roboh. Ajir harus kuat, dan ditancapkan dengan kedalam $25 \mathrm{~cm}$ dan tingginya $75 \mathrm{~cm}$.

\subsubsection{Penyulaman}

Penyulaman dilakukan jika ada tanaman yang mati dan tanaman tidak sehat. Penyulaman dilakukan seminggu setelah penanaman bibit.

\subsection{Pemeliharaan}

\subsubsection{Penyiangan}

Penyiangan dilakukan sesuai dengan kondisi tanah yaitu melihat pertumbuhan gulma. Penyiangan dilakukan saat gulma mulai tumbuh dengan cara mencabut gulma dengan tangan dan parang yang dilakukan dari mulai penanaman sampai panen.

\subsubsection{Penyiraman}

Pada awal penanaman hingga panen dilakukan penyiraman dengan air yang cukup agar tanaman tidak stres. Penyiraman dilakukan untuk menjaga kelembaban tanah agar tanaman dapat tumbuh dengan baik. Penyiraman dilakukan pagi dan sore hari sesuai keadaan kelembaban tanah. Bila hari hujan tidak dilakukan penyiraman.

\subsubsection{Pemangkasan}

Dalam pemangkasan perlu dilakukan terhadap tunas-tunas air, daun tua daun yang terserang penyakit, buah yang cacat, rusak dan terserang hama penyakit dengan menggunakan gunting yang bertujuan tidak menularkan ketanaman lain. Hal ini dilakukan sesuai keadaan tanaman. Pemangkasan dilakukan agar memacu pertumbuhan yang baik pada cabang yang produktif dan juga dalam pertumbuhan tanaman.

Pemangkasan daun-daun tua, daun yang terserang penyakit bertujuan untuk mempelancar sinar matahari yang masuk ketanaman, mengurangi resiko penularan hama penyakit. Waktu pemangkasan baik dilakukan pada pagi hari, karena setelah 
dipangkas bagian dipotong menjadi kering tidak terserang patogen.

\subsubsection{Pengendalian Hama dan Penyakit}

Pengendalian serangan hama dilakukan dengan penyemprotan insektisida Sevin 85 SP dengan dosis 2cc/liter air. Penyemprotan dilakukan 2 minggu setelah penanaman. Sedangkan untuk pencegahan penyakit dilakukan penyemprotan Fungisida Dithane M-45 dengan dosis 2 gr/liter air. Bila terjadi serangan hama disaat setelah pencegahan maka dilakukan pengambilan hama dengan menggunakan tangan dan memotong bagian yang terkena serangan hama. Jika terjadi serangan penyakit setelah pencegahan dilakukan penyemprotan berulang pada tanaman yang terserang.

\subsubsection{Pemanenan}

Pemanenan dilakukan apabila telah memenuhi kriteria buah kuning kemerahmerahan, keadaan buah belum lunak. Cara pemanenan buah tomat dilakukan dengan menggunakan cara memetik dengan gunting sampai ke tangkai tomat. Panen dilakukan sebanyak tiga kali dan interval 3 hari.

\subsection{Pengamatan}

\subsubsection{Perubahan pH Tanah}

Pengamatan $\mathrm{pH}$ tanah dilakukan sebanyak 2 kali yaitu sebelum dilakukan pemberian dolomit dan seminggu setelah pemberian dolomit sesuai dengan perlakuan. Pengamatan $\mathrm{pH}$ bertujuan untuk mengetahui perubahan $\mathrm{pH}$ sebelum dan setelah pemberian dolomit sesuai perlakuan, tetap tidak merubah dosis perlakuan pemberian dolomit.

\subsubsection{Pengamatan Tinggi Tanaman} Pengamatan tinggi tanaman dilakukan diakhir tanaman. Pengukuran tinggi tanaman dilakukan dimulai dari pangkal ajir yang ditancapkan dengan ditandai pengikatan dan pemberian tanda di ajir tersebut.

\subsubsection{Umur Bunga Pertama}

Pengamatan bunga pertama mulai saat dari penanaman sampai tanaman mengeluarkan bunga pertama. Pengamatan dilakukan dengan menghitung pada hari keberapa bunga tersebut muncul dan diamati pada tanaman. Hal ini bertujuan untuk mengetahui masa vegetatif dan generatif tanaman.

\subsubsection{Umur Panen Pertama}

Umur panen pertama dihitung mula dari penanaman sampai panen pertama. Dengan kriteria buah kuning kemerah- merahan, keadaan buah belum lunak

\subsubsection{Bera $t$ perBuah Tanaman}

Berat buah per tanaman diperoleh dengan menghitung berat buah panen pertama sampai panen ketiga per tanaman.

\subsubsection{Berat Brangkasan Kering}

Berat brangkasan kering diperoleh dari satu tanaman tomat bagian batang dan daun selain buah dan akar setelah itu dimasukan dalam map yang telah dilobangi kemudian dioven selama 48 jam dengan suhu $70^{\circ}$ setelah dioven brangkasan kering dibuka dari map dan ditimbang dengan menggunakan timbangan digital.

3.

\section{HASIL DAN PEMBAHASAN}

\section{$4.1 \mathrm{pH}$}

Pengamatan $\mathrm{pH}$ tanah yang dilakukan sebelum dilakukan perlakuan dan setelah perlakuan pemberian dolomit sesuai perlakuan. Tujuan pengamatan $\mathrm{pH}$ ini untuk mengetahui berapa $\mathrm{pH}$ tanah dengan penambahan dolomit sesuai perlakuan.

Analisis sidik ragam (Lampiran 6) menunjukkan bahwa perlakuan pemberian dolomit terhadap $\mathrm{pH}$ tanah gambut memperlihatkan pengaruh nyata terhadap peningkatan $\mathrm{pH}$ tanah gambut. Hasil uji lanjut dengan Tukey HSD taraf 5\% pengamatan $\mathrm{pH}$ tanah awal dan sesudah pemberian dolomit dapat dilihat pada Tabel 1

Tabel 1. Pengaruh Pemberian Dolomit terhadap pH Tanah Gambut

\begin{tabular}{lc}
\hline Perlakuan & pH Sesudah \\
\hline Tanah Gambut & \\
Tanah Gambut + $200 \mathrm{~kg} \mathrm{SP}-36$ / Ha & \\
+2 Ton dolomit / Ha & 4.50 \\
Tanah Gambut + $200 \mathrm{~kg} \mathrm{SP}-36$ / Ha & $\mathrm{b}$ \\
+3 Ton dolomit / Ha & $6.00 \mathrm{a}$ \\
Tanah Gambut + 200 kg SP-36 / Ha & $6.33 \mathrm{a}$ \\
+4 Ton dolomit / Ha & $6.67 \mathrm{a}$ \\
Tanah Gambut + 250 kg SP-36 / Ha & $6.00 \mathrm{a}$ \\
+2 Ton dolomit / Ha & $6.33 \mathrm{a}$ \\
Tanah Gambut + 250 kg SP-36 / Ha & $6.67 \mathrm{a}$ \\
+3 Ton dolomit / Ha & \\
Tanah Gambut + 250 kg SP-36 / Ha & \\
+4 Ton dolomit / Hat & \\
KK : 7,34 & \\
\hline
\end{tabular}

KK : 7,34

Keterangan : angka - angka yang diikuti huruf kecil yang sama menunjukkan berbeda nyata pada taraf $5 \%$ menurut uji Tukey HSD 
Pemberian dolomit dapat meningkatkan $\mathrm{pH}$ tanah karena $\mathrm{OH}^{-}$akan menetralkan $\mathrm{H}^{+}$dalam larutan tanah (Sutanto, 2005). Selanjutnya Kuswandi (1993), berpendapat bahwa pemberian dolomit pada tanah masam dengan bahan yang mengandung $\mathrm{Ca}$ atau $\mathrm{Mg}$ akan mengubah atau menggeser kedudukan $\mathrm{H}^{+}$di permukaan koloid, sehingga menetralisasi keasaman tanah. Selain itu kalsium dan $\mathrm{Mg}$ dapat juga bergabung dengan asam terlarut yang ada sehingga keasamannya rusak dan pada akhirnya $\mathrm{pH}$ tanah meningkat. Dengan pemberian dosis dolomit yang sama semakin meningkatnya pemberian dosis SP-36 mampu meningkatkan tinggi tanaman. Hal ini mengindikasikan bahwa perlakuan pupuk fosfor sangat baik digunakan untuk menambah unsur hara tanah dalam membantu pertumbuhan tinggi tanaman. Hara $\mathrm{P}$ sangat diperlukan tanaman terutama pada saat awal pertumbuhan. Pada fase pertumbuhan tanaman tersebut, unsur $P$ berfungsi memacu pembentukan akar, pembungaan, pemasakan biji/buah. Selain itu $\mathrm{P}$ berfungsi merangsang pembelahan sel, lemak dan protein.

\subsection{Tinggi Tanaman}

\subsection{Umur Berbunga}

Analisis sidik ragam (Lampiran 6) menunjukkan bahwa perlakuan pemberian Dolomit dan SP-36 berbeda nyata terhadap tinggi tanamanDengan pemberian SP-36 yang sama semakin meningkatnya pemberian dosis dolomit mempercepat pembungaan. Hal ini disebabkan penambahan pemberian dolomit menaikan keadaan $\mathrm{pH}$ tanah, sehingga dengan meningkatnya $\mathrm{pH}$ tanah maka ketersediaan dan penyerapan $\mathrm{P}$ semakin meningkat. Fungsi $P$ beguna untuk pembungaan, pengisian biji dan pemasakan buat tanaman.

Menurut Soernajono (1977) tersedia unsur makro seperti fosfat sangat menguntungkan bagi tanaman dalam bentuk bunga. Menurut Novizan (2007), bahwa pemupukan fosfat dapat merangsang pertumbuhan bibit awal, fosfor merangsang pembentukan bunga, buah dan biji menjadi bernas.

Selain penambahan fosfat dan dolomit umur berbunga dipengaruhi faktor genetik. Faktor genetik merupakan sifat yang diturunkan induknya, sifat ini dipengaruhi oleh lingkungan. Sedangkan faktor lingkungan adalah tempat tumbuh, ketinggian tempat, iklim, suhu, dan perlakuan (Setiadi, 1990).

\subsection{Umur Panen Pertama}

Analisis sidik ragam (Lampiran 6) menunjukkan bahwa perlakuan pemberian Dolomit dan SP-36 berbeda nyata terhadap umur panen pertama.

Dengan pemberian dosis dolomit yang sama semakin meningkatnya pemberian dosis SP-36 mempercepat umur panen tanaman. Hal ini karena pemberian dolomit menaikan keadaan $\mathrm{pH}$ tanah, menyediakan dan memudahkan penyerapan $\mathrm{P}$ yang diberi pemberian SP-36 memudahkan penyerapan $P$ sehingga mempercepat pembungaan, pengisian biji dan pemasakan buat tanaman. Menurut Hardjadi (1984) mengemukakan bahwa unsur hara yang tersedia bagi tanaman melalui proses fotosintesis menghasilkan karbohidrat yang kemudian diangkut kedalam organ tanaman, hal ini akan merangsang, pertumbuhan, perpanjangan dan pembesaran tanaman bagian vegetatif maupun generatif.

Fosfor berfungsi sebagai bahan mentah untuk pembentukan tertentu, membantu asimilasi dan pernapasan, serta mempercepat pembungaan, pemasakan biji dan buah (Lingga dan Marsono, 2007).

\subsection{Berat Buah per Tanaman (gram)}

Analisis sidik ragam (Lampiran 6 ) setelah diuji lanjut dengan uji Tukey HSD pada taraf terkecil 5\% menunjukkan bahwa perlakuan pemberian Dolomit dan SP-36 terhadap berat buah berbeda nyata. Dengan pemberian dolomit yang sama semakin meningkat pemberian dosis SP-36 meningkatkan berat buah per tanaman. Hal ini karena pemberian dolomit menaikan $\mathrm{pH}$ tanah (Tabel 1) sehingga memudahkan menyerapan $P$, dengan penambahan SP-36 dapat menambah berat buah tanaman karena $P$ berfungsi mempercepat pembungaan dan mempercepat kemasakan buah tanaman.

Berat buah sangat dipengaruhi oleh unsur hara $P$ dan unsur ini sangat diperlukan dalam fase generatif yakni pembentikan buah setelah memasuki fase generatif. Menurut Lingga (2007) fosfor dapat merangsang pertumbuhan akar muda, pemasakan buah dan biji.

Ketersedian hara makro dan mikro bagi tanaman yang diberikan melalui pemupukan merupakan hal yang sangat mendukung pertumbuhan tanaman baik pertumbuhan vegetatif maupun generatif, terpenuhi batas maksimum unsur hara yang diberikan pada tanaman merupakan faktor utama yang mempengaruhi pertumbuhan 
tanaman seperti berat buah ( Rinsema, 1986).

\subsection{Berat Brangkasan Kering}

Analisis sidik ragam (Tabel 6) menunjukkan bahwa perlakuan pemberian Dolomit dan SP-36 terhadap berat brangkasan kering berbeda nyata. Dengan pemberian dolomit yang sama semakin meningkatnya pemberian dosis SP-36 meningkatkan berat brangkasan kering tanaman. Hal ini karena pemberian dolomit menyediakan ketersediaan $\mathrm{P}$ dan menudahkan penyerapan $\mathrm{P}$ kenaikan berat brangkasan kering karena peranan $P$ membantu pembelahan sel dan meningkatkan pertumbuhan tanaman dengan meningkatnya pertumbuhan maka berat brangksan kering juga meningkat. Peranan Dolomit terkandung $\mathrm{Ca}$ dan $\mathrm{Mg}$ membantu pertumbuhan tanaman baik awal penanaman dan merangsang perakaran juga membantu peroses fotosintesis.

Perlakuan tanah gambut dibandingkan pemberian SP-36 dan dolomit mampu meningkatkan berat brangkasan kering, sehingga dengan pemberian dolomit yang sama penambahan pemberian SP-36 meningkatkan berat brangkasan kering tanaman. Hal ini karena pemberian dolomit menyediakan ketersediaan $\mathrm{P}$ dan menudahkan penyerapan $P$ kenaikan berat brangkasan kering karena peranan $P$ membantu pembelahan sel dan meningkatkan pertumbuhan tanaman dengan meningkatnya pertumbuhan maka berat brangksan kering juga meningkat. Peranan Dolomit terkandung $\mathrm{Ca}$ dan $\mathrm{Mg}$ membantu pertumbuhan tanaman baik awal penanaman dan merangsang perakaran juga membantu peroses fotosintesis.

Kegiatan fotosintesis yang optimal membantu peningkatan bahan organik pada tanaman sehingga berat tanaman meningkat dan meningkatkan bahan organik (Nyakpa et al, 1988).

\section{KESIMPULAN DAN SARAN}

Bedasarkan dari penelitian yang telah dilaksanakan maka dapat disimpulkan bahwa :

1. Pemberian SP-36 dan dolomit dapat meningkat $\mathrm{pH}$ tanah gambut, tinggi tanaman, umur berbunga, umur panen, berat buah per tanaman dan brangkasan kering tanaman.
2. Perlakuan dosis yang terbaik pada perlakuan $250 \mathrm{~kg} \mathrm{SP}-36 / \mathrm{Ha}+4$ Ton dolomit / $\mathrm{Ha}$.

\subsection{Saran}

Dilihat dari hasil penelitian produksi belum mencapai deskripsi tanaman disarankan penelitian selanjutnya memberikan pupuk dasar Urea dan $\mathrm{KCl}$ sesuai perlakuan.

\section{DAFTAR PUSTAKA}

Badan Pusat Statistik. 2014. Produksi Sayuran Indonesia. hhtp://www..bps.go.id.id/tab/su b/wiev.php?kat $=3 \&$ table $=1 \&$ daf tar $=1 \%$ id_subjek $=55 \&$ notab $=2$ 7. Diaskes 11 maret 2016.

Badan Pusat Statistik dan Jendral Hortikultura, 2012. Data Produksi dan Produktifitas tomat menurut tahun 2007-2010. Data statistik/produksi/produktifitasto mat/pdf/htm. Diaskes pada tanggal 20 febuari 2013.

Cahyono, B. 2008. Usaha tani dan penanganan pasca panen tomat. Yogyakarta : Kanisus.

Fauzi. 2010. Uji Beberapa Jenis Mikroorganisme Selulolitik terhadap Pertumbuhan dan Produksi Kedelai (Glycine max L.) di Lahan Gambut. Skripsi.Fakultas Pertanian. Universitas Riau. Pekanbaru. 35 Hal.

Hakim, N, M,Y Yakpa, A,M, Lubis, S dan H,H, Bailey, 1986. Dasar-dasar Ilmu Tanah, Penerbit Universitas Lampung.

Handayani, I.P. 2004.Studi Pemanfaatan Gambut Asal Sumatera: Tinjauan Fungsi Gambut sebagai Bahan Ekstraktif, Media Budidayadan Peranannya dalam Retensi Carbon. Wetlands International. Climate Change, Forests and Peatlands in Indonesia. Fakultas Pertanian. Universitas Sumatera. 232 hal.

Hardjadi, S. S. 1984. Pengantar Agronomi. Gramedia. Semarang

Ismail. F. 2013, Pengaruh Pupuk 
Phosfor Terhadap Pertumbuhan Jagung Hibrida. Skripsi: Fakultas Pertanian Universitas Negeri Gorontalo.

Jones, U.S. 1979. Fertilizer and Soil Fertility. A Prencite Hall. Reston Publ. co.Virginia.

Kasno. A. , D. Setyorini, dan E. Tuberkih. 2006. Pengaruh Pemupukan Fosfat Terhadap Produktivitas Tanah Inceptisol dan Ultisol. ISSN 1411 - 0067Jurnal IImu-IImu Pertanian Indonesia. Volume 8 No. 2 . http://repository.unib.ac.id/51/ 1/91JIPI-2006.pdf. $\square 15$ jun 2013

Kuswandi. 1993. Pengapuran Tanah

Pertanian. Kanisius. Yogyakarta.

Lakitan, B, 2007. Petunjuk Penggunaan Pupuk, Penebar Swadaya.

Lingga, P dan Marsono. 2007. Petunjuk Penggunaan Pupuk. Penebar Swadaya. Jakarta. 150 hal.

Noor, M. 2001, Pertanian Lahan Gambut Potensi dan Kendala. Kalimantan.

Nurita dan Anwar, K. (2007), pemanfaatan residu fosfatpada tanaman padidilahan sulfat masam. Prosiding Simposium Penelitian Tanaman Pangan IV.

Novizan. (2007). Petunjuk Pemupukan Yang Efektif. Jakarta: PT. Agro Media Pustaka.

Nyakpa. M. Y. dkk 1998. Kesuburan Tanah. Universitas Lampung.

Onggo, T, M. 2001. Pertumbuhan Dan Hasil Tanaman Tomat Pada Aplikasi Berbagai Formula Dosis Pupuk Majemuk Lengkap.Skripsi. Fakultas Pertanian Unpad.

Parinduri, P. 2011. Penetapan Dosis Dan Waktu Pemupukan Sp-36 Pada Tanah Sulfat Masam Untuk Mendukung Pertumbuhan Padi (Oryza sativa L.) ditanah sulfat masam.Skripsi. Universitas Sumatera Utara. Sumatra Utara $23 \mathrm{Hal}$.
Pudjiatmoko. 2008. Budidaya Tomat. Jurnal Atani Tokyo. http://www.atanito/son blogspot.com (2 )ber 2010).

Purwono dan Purnamawati (20C, laya Tomat dan Pemupuk han Gambut. Penebar ya. Jakarta.

Rinsema. $1986 . \quad$ Budidaya Tanaman. Gramedia. Semarang

Sagiman, S. 2001. Peningkatan Produksi Kedelai di Tanah Gambut Melalui Inokulasi Bradyrhizobium Japonicum dan Pemanfaatan Bahan Amelioran (Lumpur dan Kapur). Desertai Program Paska Institute Pertanian Bogor.

Setiadi, B. 1990. Masalah Gambut Indonesia. Editor Himpunan gambut. 61 hal.

Soernajono.1977.Fisiologi

Tanaman Budidaya. Universitas Indonesia Press. Jakarta.

Subagyo, H. (2000). Inventarisasi Karakteristik Tanah Gambut Sebagai Penunjang Pengelolaan Hutan Produksi Lestari. Dalam Prosiding Seminar Pengelolaan Hutan Rawa Gambut dan Ekspose Hasil Penelitian di Hutan Lahan Basah di Balai Teknologi Reboisasi Banjarbaru; Banjarbaru 9 Maret 2000. PUSLITBANG Hutan dan Konservasi Alam Bogor. Hal: 126-137.

Sugito, 2002. Bertanam Jagung Manis. PT. Penebar Swadaya Jakarta.

Sutanto, R. 2005. Dasar-Dasar IImu Tanah: Konsep dan Kenyataan. Kanisius. Yogyakarta.

Taher, A. 2007.Pemanfaatan Timbunan Fosfat dilahan Sawah. Prosiding Simposium Penelitian Tanaman Pangan. Kerjasama Himpunan Gambut Indonesia dengan Badan Pengkajiandan Peerapan Penelitian. 
Yakpa,M,Y, Lubis A.M Amrah,AG,Munawar,A.

Hong $G, B$, Hakim. N

1988. Kesuburan tanah.

Universitas Lampung. Lampung.

Yanti, M. 2015. Respon Pertumbuhan dan Hasil Tanaman Tomat Terhadap Pemberian Pupuk Kandang dan Kapur Dolomit pada Tanah Gambut.Skripsi.Fakultas Pertanian. Universitas Muhammadiyah. Palangkaraya.

Widodo. 2000. Pupuk yang Akrab Lingkungan, dalam Majalah Komoditas Edisi Khusus, Tahun II, 3-26 Januari 2000.

Wiryanta, B.T.W. 2002.Kiat Pengatasi Permasalahan Praktis Bertanam Tomat. Jakarta: Agro Media Pustaka. 